IJSHE

8,3

272

\section{Institutional commitment to sustainability}

\section{An evaluation of natural resource extension programs in universities in Alabama and Oregon}

\author{
Shorna R. Broussard \\ Department of Forestry and Natural Resources, Purdue University, \\ West Lafayette, Indiana, USA, and \\ John C. Bliss \\ Department of Forest Resources, Corvallis, Oregon, USA
}

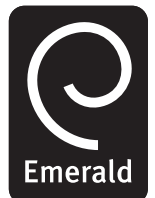

International Journal of Sustainability in Higher Education

Vol. 8 No. 3, 2007

pp. $272-284$

(C) Emerald Group Publishing Limited 1467-6370

DOI $10.1108 / 14676370710817147$

\begin{abstract}
Purpose - The purpose of this research is to determine institutional commitment to sustainability by examining Natural Resource Extension program inputs, activities, and participation.

Design/methodology/approach - A document analysis of Natural Resource Extension planning and reporting documents was conducted to provide contextual and historical data for the study and 58 in-depth interviews were conducted with Natural Resource Extension personnel in the Alabama Cooperative Extension System and the Oregon State University Extension Service.

Findings - This research moves beyond the familiar teaching and research functions of higher education institutions and focuses on Cooperative Extension, which is the outreach arm of universities. The paper discusses challenges and opportunities associated with implementing sustainability through these outreach education programs. In both Alabama and Oregon, the Agriculture, Home Economics, and 4-H programs dominate human and economic resource investment in Cooperative Extension. Natural Resource Extension programs in Alabama and Oregon represents 6 and 14 percent, respectively, of all program expenditures in Cooperative Extension. Both states have educational programs that address sustainability of natural resources and those programs were interdisciplinary in nature. Little evidence is found extensive participation in Natural Resource Extension programs by environmental groups, minorities, and other non-traditional clientele. Lastly, Oregon's political context was more conducive to broadening Natural Resource Extension program work in sustainability.

Practical implications - Educational institutions such as Natural Resource Extension programs at universities play a significant role in educating private landowners, the public, and professionals about various aspects of forestry and natural resources. Based on this study of Natural Resource Extension programs in Alabama and Oregon, the following are needed for extension to address natural resource sustainability through its educational programs: sufficient intellectual and financial commitment to sustainability, diverse and inclusive participation in programs, and collaborative interdisciplinary programming. The analysis presented here can aid other educators as they explore sustainability through educational programming.

Originality/value - Since, Natural Resource Extension programs address societal concerns through problem solving, grassroots education, and research and technology dissemination, they are poised to do work in the sustainability arena. No study to date has examined sustainability from the aspect of Natural Resource Extension educators in Oregon and Alabama. An understanding of current investment in sustainability through education is fundamental to building a strong Extension program in this area.
\end{abstract}

Keywords Education, Natural resources, Agriculture, Sustainable development, United States of America

Paper type Case study 


\section{Introduction}

Sustainable development, characterized by the union of economic growth, environmental protection, and social equity, is at the forefront of national and international policy and research agendas. Sustainable development can be defined as "development that meets the needs of the present without compromising the ability of future generations to meet their own needs" (World Commission on Environment and Development, 1987, p. 8). In 1996, the United States Department of Agriculture (USDA) made a commitment to integrate the goals and concepts of sustainability throughout its agencies, policies, and programs. One such program is Cooperative Extension, which is an educational partnership between the 105 land grant colleges and universities in the USA and USDA. Cooperative Extension is a unique system of public outreach that exists in over 9,000 US counties, has close links to local communities, a science-base at land-grant universities, and a tradition that spans more than 80 years. The land-grant university three part mission of teaching, research, and extension serves as the foundation for Cooperative Extension programs. Educational institutions such as these are essential to implementing sustainability (Deason, 1996).

Some controversy surrounds sustainability, mainly related to arguments about whose values should take precedence in defining it. Thus, using the term "sustainability" conveys ideological, political, moral, and scientific views and can involve controversial topics such as limits to growth, social inequality, and economic diversification. Achieving and utilizing sustainability requires an examination of the political, economic, and social underpinnings of society. For example, it has been argued that forms of economic, social, and political subordination will continue to exclude marginalized groups (on the basis of "skin color, religion, culture, ethnicity, or any alternative conception of otherness") from the sustainability debate. These conflicting definitions and interpretations have led to some controversy over the notion of sustainability (Filho, 2000; Prugh et al., 2000). Regardless of the differing definitions, the US public is increasingly concerned with sustainability as it relates to the natural resources and the environment (Schneider and Smallidge, 2000) and sustainability is an important concept for institutions of higher education (Filho, 2000; Wright, 2002; Deason, 1996).

While sustainability is a term that has been gradually incorporated into many program areas in extension, the longest tradition of sustainability is in the Natural Resource Extension program area (Guy and Rogers, 1999). This is intuitive, as sustainability's roots are in renewable resources such as forests and fisheries (Lele, 1991). Researchers have examined attitudes and perspectives toward sustainability in Cooperative Extension. Agricultural scientists at land-grant universities perceive agricultural sustainability as most closely tied to environmental quality and less tied to economic and social aspects of sustainability (Lyson, 1998). Similarly, extension professionals in North Carolina possessed favorable attitudes toward sustainable agriculture in general but the social aspects of sustainability (equity, participation, etc.) were not endorsed as strongly as were the economic and ecological aspects of sustainability (Minarovic and Mueller, 2000). In addition, Lyson (1998) found discipline-related diversity in attitudes toward sustainability. In fact, 84 percent of academics in forestry reported that environment was an important goal above all other dimensions of sustainability, while the social dimension of sustainability was the most important goal above all others for social scientists and economists.
Institutional commitment to sustainability

273 
IJSHE

8,3

274

Thus, sustainability calls for inter-disciplinary, collaborative work in order to achieve a balance of all aspects of sustainability (Lyson, 1998; Filho, 2000).

With regard to the focus of land grant universities and Cooperative Extension, Meyer (1997) suggested a wider definition of agriculture, moving beyond agricultural production to encompass environmental management of all lands (Meyer, 1997). As Brown (1999, p. 13) once declared, "it is time to shift the basic mission of the Land Grant Colleges of Agriculture from agricultural production to that of land stewardship in all of its aspects". While budgets for extension have been disproportionately committed to the agriculture community and to the benefit of farmers and ranchers (Mc Dowell, 1991), land-grant university personnel believe that environmental issues will be the driving force for land grant Colleges of Agriculture and that environmental interests should also be included as clientele of extension (Meyer, 1995).

Researchers have examined attitudes and perspectives toward sustainability in Extension (Francis et al., 1988; Korsching and Malia, 1991; Minarovic and Mueller, 2000; Lyson, 1998), however, no study has examined sustainability from the aspect of Natural Resources Extension educators and programs. Natural Resource Extension programs play a significant role in educating private landowners, the public, and professionals about various aspects of forestry and natural resources. Two state extension systems, the Alabama Cooperative Extension System (ACES) and the Oregon State University Extension Service (OSUES), served as cases in this research. The two states were selected because they provided different political, environmental, and organizational contexts as Oregon and Alabama (Figure 1) vary in the size, scope, and organization of their respective extension programs. Oregon has the largest Extension Forestry program in the nation and this was part of the rationale for selecting this case. Alabama's Forestry Extension program is more typical of other

Figure 1.

US map with study sites indicated, Alabama (AL) and Oregon (OR)

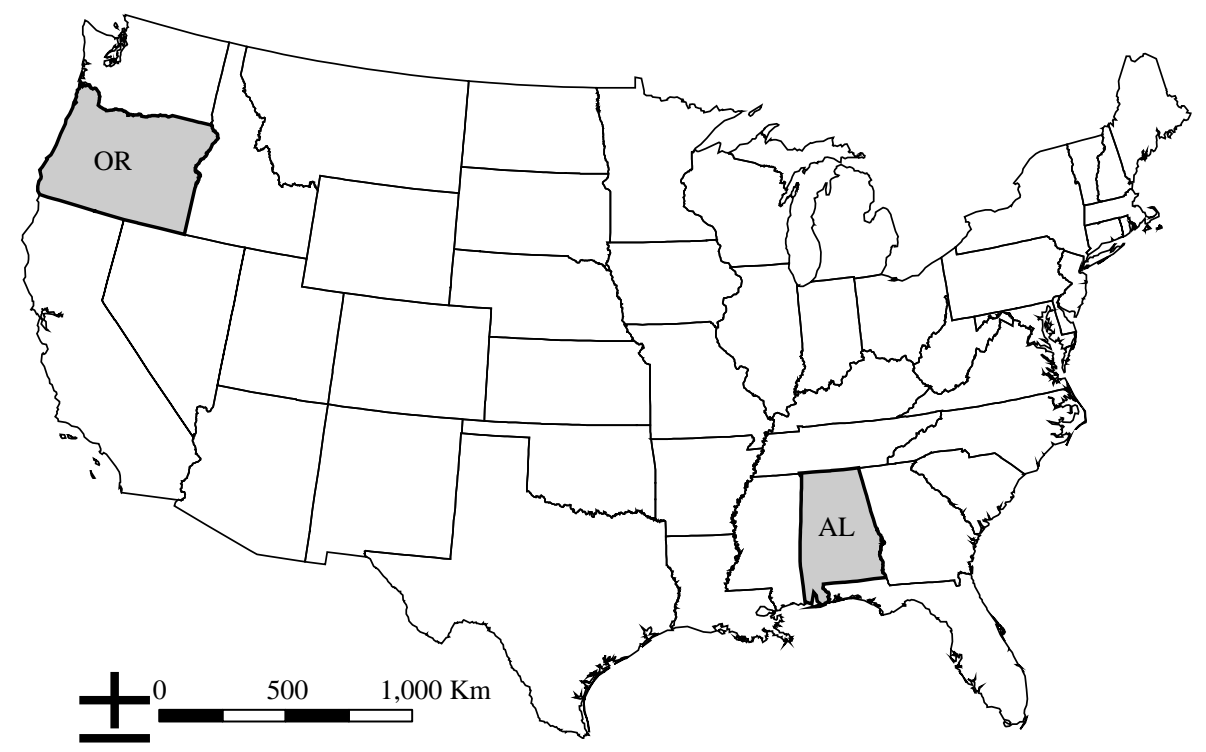


states: only a handful of campus-based extension specialists and no county extension foresters (Table I). The Oregon State University Extension Service employs approximately 313 people and the Alabama Cooperative Extension System about 337. Alabama has approximately 250 county extension staff and 80 campus-based extension specialists, while Oregon has about 190 county extension staff and 120 campus-based specialists. Secondly, the states also have different natural resource contexts. For example, while Alabama's forests are mostly privately owned, Oregon's forests are predominantly publicly owned (Table II). Forests occupy 45 percent of Oregon's total land area contrasting with the 68 percent in Alabama. The forest products payroll in Oregon stands slightly higher at $\$ 1.72$ billion compared to Alabama's $\$ 1.54$ billion. Forests are a tremendous natural resource in both states and a critical component of each state's ecological, social, and economic landscape.

\section{Methodology}

For the purposes of this study, the following methods were used: document analysis and semi-structured interviews. Semi-structured interviews were utilized because this approach allowed for some flexibility for discussion during the interviews while ensuring that a standard set of questions was asked of every interviewee. A document analysis of Natural Resource Extension planning and reporting documents was conducted to provide contextual and historical data for the study. Overall, 29 Natural Resource Extension personnel in the Alabama Cooperative Extension System and 29 Natural Resource Extension personnel in the Oregon State University Extension

\begin{tabular}{lcc}
\hline & Oregon extension & Alabama extension \\
\hline Number of county extension agents & 189.03 & 254 \\
Number of campus extension & 123.88 & 82.5 \\
specialists/administrators & $77.23^{\mathrm{a}}$ & 50 \\
College of Agriculture/Agricultural Sciences & 9.13 & $5.5^{\mathrm{b}}$ \\
College/School of Forestry & 5.65 & 7 \\
College of Home Economics/Human Sciences & 14.15 & 20 \\
Other specialists (liberal arts, business, etc.) & 312.91 & 336.5 \\
Total extension agents, specialists, administrators &
\end{tabular}

\section{Institutional commitment to sustainability}

275

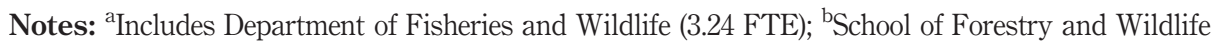
Sciences

\section{Sciences}

Number of county extension agents

specialists/administrators

College/School of Forestry

Other specialists (liberal arts, business, etc.)

\begin{tabular}{lcccc}
\hline & $\begin{array}{c}\text { Acres forestland } \\
\text { (million) }\end{array}$ & Percent of total land & $\begin{array}{c}\text { Public ownership } \\
\text { (percent) }\end{array}$ & $\begin{array}{c}\text { Private ownership } \\
\text { (percent) }\end{array}$ \\
\hline Oregon & 28 & 46 & 60 & 40 \\
Alabama & 22 & 68 & 95 & 5
\end{tabular}

Sources: Oregon Department of Forestry (1999); Alabama Forestry Commission (2000)

\section{Table I.}

Budgeted full-time equivalents (FTE) for the Oregon State University Extension Service and the Alabama Cooperative Extension System 
IJSHE

8,3

\section{6}

Service were interviewed (Table III) (Figure 1). The interviews were tape recorded and subsequently transcribed and coded.

In this study, sustainability in Natural Resource Extension programs was assessed in terms of three components: inputs, activities, and participation. Inputs, activities, and participation are necessary conditions that must be met before any primary changes can occur in program participants. For example, personnel must be in place and program dollars allocated in order to develop a particular curriculum or educational program in which clientele could then participate. Inputs are the resources - staff, and dollars - that go into educational programming. Activities include the educational programs that are conducted through Natural Resource Extension. Participation describes the interaction between Natural Resource Extension staff and their clientele in programs and program planning. The program inputs, activities, and participation model is one that is commonly used in Cooperative Extension and educational evaluation research (Bennett, 1975, 1979; Summers, 1977; Christenson and Warner, 1982; Warner and Christenson, 1984; Mayeske, 1994; Bennett and Rockwell, 1995; Swanson et al., 1997).

Grounded theory procedures were used to analyze the interview transcriptions. Grounded theory was an ideal social research approach to examining sustainability in two Natural Resource Extension programs because it is best-suited for examining explanations about phenomena about which little information is known. Grounded theory uses a methodical set of procedures to inductively derive explanations about a social phenomenon. The analytical procedure involved open coding, axial coding, and selective coding. Open coding was the initial step used to analyze the data. Researchers began by reading the transcripts and describing concepts, properties, and dimensions. The next step was axial coding. This is where connections were made between categories and contextual conditions were examined. In the final analytical procedure, selective coding, the axial coding statements were integrated into core thematic categories. The outcomes of the selective coding resulted in a set of core categories, which are presented in the results.

\section{Results}

Results are presented from the two data sources utilized in this study (document analysis and in-depth interviews) using the program inputs, activities, and participation methodological framework previously outlined. Results are organized thematically by the program inputs and related factors of:

- staffing and expertise;

- budgets and funding levels;

Table III.

Number of specialists, agents, and administrators interviewed as part of the Alabama and Oregon case studies

\begin{tabular}{lcrr}
\hline & $\begin{array}{c}\text { Oregon State University } \\
\text { Extension Service }\end{array}$ & $\begin{array}{c}\text { Alabama Cooperative } \\
\text { Extension System }\end{array}$ & Total \\
\hline Extension specialists & 9 & 7 & 16 \\
County agents & 17 & 19 & 36 \\
Administrators & 3 & 3 & 6 \\
Total & 29 & 29 & 58 \\
\hline
\end{tabular}


- program activities;

- program participation; and

- political context.

\section{Institutional commitment to sustainability}

Because this research was qualitative in part, textual data such as quotes and themes from interviews will be presented in addition to the quantitative data from the document analysis. All names used in this paper are pseudonyms, but the state locations and position descriptions reflect those of actual interviewees.

\section{Staffing and expertise}

To investigate the human resources dedicated to natural resources programming, the distribution of Cooperative Extension personnel across all program areas in each state was determined. This provided a baseline from which to begin examining the commitment to natural resources education generally, with the understanding that not all personnel in natural resources are working on sustainability issues.

One major difference between Forestry Extension staffing in Alabama and Oregon is the scope of focus among county extension personnel. In Alabama, county agents are typically generalists who do not have formal forestry training; of the more than 250 county agents in the state, only one had a degree in forestry at the time of this study. Although there are nine campus-based extension specialists in forestry, there are no county agents with dedicated assignments in forestry. Those charged with forestry and natural resource extension efforts at the local level are Agriculture and Natural Resource agents. One county agent stated it best:

I have responsibilities in areas of animal and dairy science, forestry, aquaculture, small ruminants, water quality. Those are the basic ones, but I have nine different categories that I work in.

Extensive downsizing in ACES has led to the consolidation of positions and broader job responsibilities, and has increased time constraints on remaining agents. One Alabama county extension coordinator explained, "I spend a lot of time on natural resources, but most of that is spent after work because I don't have time to do it during work." Buddy Timberlake, an administrator in the state, comments, "Ten years ago we had over 400 agents; today we have 226."

In contrast, there were 18 county extension agents in Oregon who had dedicated assignments in forestry and were able to specialize in particular aspects of the discipline, such as forest products or forest engineering. These agents generally had degrees in forestry. In addition, OSUES has ten campus-based forestry extension specialists. Oregon also has one agent dedicated to sustainable forestry issues as Associate Director of the Sustainable Forestry Partnership. In addition, an Oregon Extension Specialist heads the Sustainable Living program, which encourages environmentally sound consumerism. Oregon's population (3.3 million) is about two-thirds of Alabama's (4.4 million) and Alabama has more of its total land area in forest acreage. Yet the county agents in Alabama, those closest to communities and forests, are generalists with responsibilities in multiple program areas. 


\section{IJSHE \\ 8,3}

\section{8}

Table IV.

Expenditures by program area, Oregon State University Extension System and Alabama Cooperative Extension System

\section{Budgets and funding}

In 1999, ACES spent $\$ 2.8$ million for Forestry and Natural Resource programs (Table IV). In 1998, OSUES had $\$ 3.6$ million in expenditures for the Forestry and Natural Resources program areas (Table IV). The Agriculture, Home Economics, and 4-H programs account for most of program area expenditures in both states (Table III). Forestry and Natural Resource program areas command minor percentages of total program expenditures in both Alabama and Oregon extension. Though the Oregon State University Extension Service has the largest Forestry Extension program in the nation, this program area garners only 14 percent of total program area expenditures, ranking last of all the program areas. In Alabama, where there are even fewer Forestry Extension staff - only seven compared with Oregon's 28 - the lower ranking is even more pronounced.

Extension in both Oregon and Alabama has undergone significant restructuring and downsizing in the past. For example, in ACES (1998) faced a budget shortfall of over $\$ 1$ million due to a 7.5 percent across-the-board cut to higher education in 1995-1996. Between 1998 and 2000, ACES (1999a, b) eliminated or reconfigured over 80 positions. George Barish, a county agent in the state explained the consolidating effects of downsizing:

When I came here 11 years ago ... there were three of us working in the area of horticulture. The other two gentlemen took early retirement due to our downsizing and I've picked up all of the responsibilities.... Obviously it is impossible to do everything that three of us did 11 years ago so I've just been spread out a lot more and obviously can't focus quite as well as I could 11 years ago. The downsizing has forced county agents to be generalists covering multiple program areas and making it difficult to specialize.

In both Alabama and Oregon, the Agriculture, Home Economics, and 4- $\mathrm{H}$ base programs dominate expenditures (Table IV). This result is even more stark in light of the fact that the Oregon State University Extension Service has the largest Forestry Extension program in the nation, employing 28 Extension Foresters at the state and county levels, yet Forestry and Natural Resource Extension personnel in Oregon account for only 14 percent of total program area expenditures in the state - one of the smallest program percentages (Table IV).

The dominance of agriculture in extension staffing and budgets has several implications. Agriculture has long been criticized in Extension for focusing exclusively

\begin{tabular}{lrrrr}
\hline & \multicolumn{2}{c}{ Oregon } & \multicolumn{2}{c}{ Alabama } \\
& \multicolumn{1}{c}{ Dollars } & Percent & Dollars & Percent \\
\hline Agriculture & $12,341,831$ & 49 & $15,816,432$ & 34 \\
Home economics/family & $3,856,822$ & 15 & $16,016,640$ & 34 \\
4-H/Youth development & $5,656,672$ & 22 & $6,653,424$ & 14 \\
Urban programs & $\mathrm{n} / \mathrm{a}$ & $\mathrm{n} / \mathrm{a}$ & $3,650,304$ & 8 \\
Forestry and natural resources & $3,599,699$ & 14 & $2,779,632$ & 6 \\
Community resource dev. & $\mathrm{n} / \mathrm{a}$ & $\mathrm{n} / \mathrm{a}$ & $1,643,568$ & 4 \\
Total & $25,712,148$ & 100 & $46,560,000$ & 100
\end{tabular}

Sources: Oregon State University Extension System (1999) and ACES (1999b) 
on production. Part of natural resources sustainability is broadening the focus beyond production and recognizing social and environmental values. Yet analysis of budget and staffing documents does not reveal that this change has taken place. This provides evidence that a balance is needed between dollar and staffing allocations among program areas in Extension.

Program activities

Sustainability is inter-disciplinary in nature, thus extension programs that incorporate multiple disciplines are more likely to provide a holistic view of education. In Oregon, the Watershed Stewardship Enhancement Program (WSEP) involves faculty from program areas and academic units such as Sociology, Forestry, Wildlife, Political Science, Sea-Grant, Community Development, and Watershed Management. The WSEP is a multidisciplinary educational curriculum aimed at educating watershed restoration groups and citizens about watershed ecosystems and how to work effectively in groups to achieve goals of watershed stewardship. WSEP faculty received a $\$ 10,000$ innovative project grant from OSU Extension in 1997. WSEP covers topics of: watershed processes, stream ecology, evaluation and reduction of upland erosion, riparian area functions and management, evaluating and improving fish habitat, wetland/estuary evaluation and enhancement, working together to create successful groups, water quality monitoring. The audience for WSEP is watershed groups, farmers, foresters, and urban residents.

An example of an Alabama natural resource extension program that incorporates the concepts of sustainability is the C. Beaty Hanna Urban Horticulture and Environmental Center in Birmingham, which serves the educational needs of urban residents. The Urban Horticulture and Environmental Center is a collaborative effort between ACES, the Birmingham Botanical Gardens, Jefferson County Commission, Birmingham Botanical Society, and the City of Birmingham. The Jefferson County Commissioners committed a quarter million dollars to the Center. Programs delivered at the Center cover topics such as environmental issues, erosion, air quality, water quality, urban forestry, and stewardship of natural resources. More importantly the Center targets the following clientele: urban residents, commercial and horticultural professionals, and home gardeners. ACES Director Steve Jones and the School of Forestry and Wildlife Sciences Dean led the charge for hiring an urban forestry extension specialist to complement this program.

\section{Program participation: engaging non-traditional extension clientele}

The Brundtland Report (World Commission on Environment and Development, 1987) describes participation as improving the degree and quality of participation of previously disempowered groups. As applied to Extension, this involves examining clientele participation in Extension programming and planning. We examined the extent to which nontraditional clientele - clientele that have not traditionally been engaged such as minorities, small landowners, environmental groups, displaced farmers, migrant laborers, displaced workers, and low-income farmers - are involved in Extension (GAO, 1981; Wright and Priester, 1986; Enarson, 1989).

We found little evidence of participation in Natural Resource Extension programs by environmental groups, minorities, and other non-traditional clientele. Results showed that non-traditional clientele groups have educational needs that are not being served. For example, environmental groups, a non-traditional clientele, seldom 
IJSHE

8,3

\section{0}

participated in Extension programs and were rarely present on any of the county advisory boards that guide Extension programming at the local level. Many times, issues of credibility and trust surfaced during discussions of engaging environmental groups as clientele in Extension. Non-traditional clienteles' goals and ideologies may be different from those of more traditional clientele groups and Extension faculty expressed some discomfort with this unfamiliarity. In addition, Extension faculty perceived that working with groups with controversial agendas could lead to a loss of credibility for Extension. An Oregon State Extension Specialist talked about the potential loss of credibility that he perceived might accompany working with non-traditional clientele like environmental groups:

We have different values and different goals and for those of us in extension we feel it extremely important to maintain our credibility with various clientele groups. So we are very reluctant to form alliances and coalitions with non-profits because when we do that, we get oft times used. They want to use us as credibility for their cause. Even though we may agree with them, we're reluctant to tag our name on it because then all of a sudden we are on one side of an issue and we try to stay in the middle-ground.

An Extension Administrator explained the difficulties involved with meeting the educational needs of non-traditional clientele:

We can offer local groups and organizations a great deal of assistance I think, [but] we have a hard time, we are a conservative organization - and keep in mind our county agents. Unfortunately, that's somewhere where we have some vested interest. Some of these groups and organizations are not highly thought of, their objectives may be different than some of our more traditional clientele. A lot of times I'll have groups tell me 'I went to your county agent and asked for their help and they told me they couldn't do that.' What happened was, one of the things the group wanted to do was different than what the local ALFA group thought was important. So that's not good but that happens.

Also, it was not as if Extension faculty had poor working relationships with environmental groups, it was that the relationships had yet to be established. However, where relationships existed between Extension and environmental groups, it was based on communication and building trust.

From an ethnic or cultural standpoint, diversifying the composition of Extension educators would be a first step toward improving diversity in program participation. Of the 58 Natural Resource Extension agents, specialists, and administrators interviewed in Alabama and Oregon, only seven were female and only one was non-white. In both states, we observed a lack of non-traditional clientele participation. These two facts are not unrelated: a 1995 national survey of the general public found that wealthy, educated, whites who live on farms are more likely than their less educated, poorer, urban counterparts to have used extension services or have participated in its programs, neatly delineating the rural tradition of Extension (Christenson et al., 1995).

\section{Political context for sustainability}

The political context is especially favorable in Oregon for addressing natural resources sustainability due to the leadership of Oregon's former Governor (Kitzhaber), as he was a leader in the state with regard to restoring endangered salmon populations. Additionally, in Oregon, interest groups are in a dominant, yet complementary (Hrebenar, 1997) position in state politics. Also, in Oregon environmental groups such 
as the Sierra Club and Oregon Natural Resources Council rank higher than the Farm Bureau in terms of interest group influence (Hrebenar, 1997). In 1997, the Governor's Office released the "Oregon Plan for Coastal Salmon Restoration," promoting a non-regulatory cooperative approach to watershed management. Extension's role in watershed management was outlined:

The University Extension Service has a key role to play in both training and outreach for the Oregon Plan. There are two major training needs: interagency cross-training on implementation of the Oregon Plan, and training for Watershed councils, soil and water conservation districts and other local groups. University Extension is currently in the process of developing a Watershed Steward Educational Program (WSEP). WSEP is a comprehensive watershed enhancement educational program (consisting of curriculum, training materials and learning aids) that will enable target audiences to learn to form effective partnerships, to assess conditions and develop strategies for mitigating or enhancing watershed resources, and to implement effective enhancement projects. WSEP is a joint program of the agriculture, forestry and Sea Grant Extension program areas. The goal is that this program will be accepted by state and federal agencies directing salmon restoration and management programs.

Kitzhaber's policy directives to state agencies in Oregon are intended to sharpen their focus on water quality and watershed restoration as well as encourage greater coordination among the agencies involved. In addition to Governor Kitzhaber's watershed restoration initiatives, he issued an Executive Order on sustainability in 2000 to develop a state strategy promoting sustainability in internal state government operations (Executive Order-00-07). The executive order promotes collaboration between state agencies and places a premium on working together. Thus, Oregon Extension's pioneering efforts in the area of watershed management are supported by one of the state's leading political figures.

The political context for sustainability in Alabama is driven, in large part, by the power of special interests. Few states rival Alabama in terms of interest group dominance in state politics (Hrebenar and Thomas, 1992; Thomas and Hrebenar, 1996, 1999). Hrebenar and Thomas (1996) identified Alabama as one of seven states in the USA where the dominance of interest groups in the political system is greatest. In fact, the Alabama Farmers Federation ranked among the most effective interest groups in the state of Alabama (Hrebenar and Thomas, 1992). This is related to sustainability programming in that attempts to move Extension beyond agriculture production have been met with resistance by some interest groups in Alabama. The fact that some farmers and cattlemen say that Extension is straying too far from its mission and traditional role as "teacher to the countryside" (GAO, 1981, p. 15) has significant meaning coming from such an politically influential segment of society that provides the constituency support that lies at the heart of a bureaucracies survival. Constituency support is one of the major ways in which bureaucracies garner power. Oregon faced similar challenges with traditional agriculture lobbies, but interest groups' influence on state politics is less pronounced than it is in Alabama. The political context of a state is a significant factor that can influence the Extension organization and its commitment to sustainability.

\section{Recommendations}

Based on this study of Natural Resource Extension programs in Alabama and Oregon, the following are necessary for Extension to address natural resource sustainability through its educational programs: 


\section{IJSHE \\ 8,3}

\section{2}

\section{Conclusions}

Extension is well poised to foster sustainability through its educational programs. Natural Resource Extension programs at our nation's land grant universities inform and influence the knowledge and decisions of thousands of citizens across the USA. Extension educators working in over 9,000 counties in the USA can utilize their grassroots network to meet the educational needs of citizens related to sustainability. Extension educators also have much to contribute to the dialogue around sustainability and in doing so can help the public better understand issues surrounding resource sustainability. Sustainability education has the potential to play a great role in moving society towards embracing sustainability, however, there are certain practices that will help promote sustainable development within the Extension organization. The recommendations stated above should be taken into account if Extension is going to aid in educating citizens on why sustainability is important and how to go about achieving it.

Philosophical support for sustainability is but one of a constellation of factors needed to demonstrate commitment to sustainability in Extension education. Budgets, staffing, and leadership must accompany that philosophical vision. In addition, Extension must engage non-traditional clientele in Extension programs, program planning, and staffing in order to achieve equitable program participation. Improved diversity in program participation, in turn, will broaden the discourse around sustainability and better address the educational needs of non-traditional clientele. Lastly, the influence of state politics in Extension education should not be underestimated.

\section{References}

ACES (1998), Report of the Agricultural Task Force, Alabama Cooperative Extension System, Auburn University, Auburn, AL.

ACES (1999a), Facts and Figures About the Alabama Cooperative Extension System, Alabama Cooperative Extension System, Auburn University, Auburn, AL.

ACES (1999b), ACES Prioritization and Redirection Plan, Alabama Cooperative Extension System, Auburn University, Auburn, AL, available at: www.aces.edu/prp/

Bennett, C. (1975), "Up the hierarchy”, Journal of Extension, Vol. 13 No. 2, pp. 7-12. 
Bennett, C. (1979), Analyzing Impacts of Extension Programs, ESC-57, US Department of Agriculture, Science \& Education Administration, Washington, DC.

Bennett, C. and Rockwell, K. (1995), Targeting Outcomes of Programs (TOP): An Integrated Approach to Planning and Evaluation, University of Nebraska, Lincoln, NE.

Brown, R.D. (1999), "Natural resource challenges for the Land Grant Colleges of Agriculture in the 21st century", Renewable Resources Journal, Spring, pp. 12-17.

Christenson, J.A. and Warner, P.D. (1982), "An assessment model for the cooperative extension service”, Rural Sociology, Vol. 47 No. 2, pp. 369-90.

Christenson, J.A., Dillman, D.A., Warner, P.D. and Salant, P. (1995), "The public view of Land Grant Universities: results from a national survey”, Choices, Vol. 10 No. 3, pp. 37-9.

Deason, J.P. (1996), "Changing world attitudes on environmental values and sustainability: implications for education institutions", Renewable Resources Journal, Winter, pp. 6-11.

Enarson, H.L. (1989), "Revitalizing the land-grant mission", paper presented at Virginia Polytechnic Institute in August, Virginia Polytechnic Institute and State University, Blacksburg, VA.

Filho, W.L. (2000), "Dealing with misconceptions on the concept of sustainability", International Journal of Sustainability in Higher Education, Vol. 1 No. 1, pp. 9-19.

Francis, C.A., King, J.W., Nelson, D.W. and Lucas, L.E. (1988), "Research and extension agenda for sustainable agriculture", American Journal of Alternative Agriculture, Vol. 3 Nos 2/3, pp. 123-6.

GAO (1981), "Cooperative extension service's mission and federal role need congressional clarification", Report GAO/CED-81-119, General Accounting Office, Community and Economic Development Division, Washington, DC.

Guy, S.M. and Rogers, D.L. (1999), “Community surveys: measuring citizens' attitudes toward sustainability”, Journal of Extension, Vol. 37 No. 3, available at: http://joe.org/joe/1999june/ a2.html

Hrebenar, R.J. (1997), Interest Group Politics in America, M.E. Sharpe, Armonk, NY.

Hrebenar, R.J. and Thomas, C. (1992), Interest Group Politics in the Southern States, University of Alabama Press, Tuscaloosa, AL.

Korsching, P.F. and Malia, J.E. (1991), "Institutional support for practicing sustainable agriculture”, American Journal of Alternative Agriculture, Vol. 6 No. 1, pp. 17-22.

Lele, S.M. (1991), "Sustainable development: a critical review”, World Development, Vol. 19 No. 6, pp. 607-21.

Lyson, T.A. (1998), "Environmental, economic, and social aspects of sustainable agriculture in American Land-Grant Universities”, Journal of Sustainable Agriculture, Vol. 12 Nos 2/3, pp. 119-30.

Mc Dowell, G.R. (1991), The USDA and the Extension System Revisited, or, If You haven't Visited Extension Recently, You'd Better do it Soon, 'Cause It isn't Going to be there Long, Virginia Tech Agricultural Economics Extension, Blacksburg, VA.

Mayeske, G.W. (1994), Life Cycle Program Management \& Evaluation: A Heuristic Approach, Extension Service, US Department of Agriculture, Washington, DC.

Meyer, J.H. (1995), Transforming the Land Grant College of Agriculture for the Twenty-First Century, University of California, Davis, CA.

Meyer, J.H. (1997), Re-engineering the Land Grant College of Agriculture, University of California, Davis, CA.

\section{Institutional commitment to sustainability}

283 
IJSHE

8,3
Minarovic, R.E. and Mueller, J.P. (2000), "North Carolina cooperative extension service professionals' attitudes toward sustainable agriculture", Journal of Extension, Vol. 38 No. 1, available at: http://joe.org/joe/2000february/a1.html

Oregon State University Extension System (1999), A Statewide Public Service Unit of Oregon State University: Background Information, Oregon State University Extension System, Corvallis, OR.

Prugh, T., Costanza, R. and Daly, H. (2000), The Local Politics of Global Sustainability, Island Press, Washington, DC.

Schneider, R.L. and Smallidge, P. (2000), "Assessing extension educator needs in New York to address natural resource issues for the new millennium”, Journal of Extension, Vol. 38 No. 3, available at: http://joe.org/joe/2000june/a4.html

Summers, J.C. (1977), Dimensions of Program Effectiveness and Accountability, West Virginia University, Office of Research and Development, Morgantown, WV.

Swanson, B.E., Bentz, R.P. and Sofranko, A.J. (1997), Improving Agricultural Extension: A Reference Manual, Food and Agriculture Organization of the United Nations, Rome.

Thomas, C.S. and Hrebenar, R.J. (1996), "Interest groups in the states”, in Gray, V. and Jacob, H. (Eds), Politics in the American States, CQ Press, Washington, DC.

Thomas, C.S. and Hrebenar, R.J. (1999), "Who's got clout?", State Legislatures, Vol. 25 No. 4, pp. 30-4.

Warner, P.D. and Christenson, J.A. (1984), The Cooperative Extension Service: A National Assessment, Westview Press, Boulder, CO.

World Commission on Environment and Development (1987), Our Common Future, 1st ed., Oxford University Press, Geneva.

Wright, T.S.A. (2002), "Definitions and frameworks for environmental sustainability in higher education", International Journal of Sustainability in Higher Education, Vol. 3 No. 3, pp. 203-20.

Wright, J. and Priester, K. (1986), Steaks and Stakes: Extension's Linkages on the Hardwood Range, Report, Cooperative Extension, University of California, Davis, CA.

Corresponding author

Shorna R. Broussard can be contacted at: brousar@purdue.edu

To purchase reprints of this article please e-mail: reprints@emeraldinsight.com Or visit our web site for further details: www.emeraldinsight.com/reprints 